\title{
THE ENVIRONMENT IMPACT OF PHONIC POLLUTION IN AN AREA WITH HYDROCARBS EXPLOITATION ACTIVITIES
}

\author{
Viorel DRAGAN, Beatrice Daniela TUDOR \\ "Dunarea de Jos" University of Galati, Romania \\ e-mail: vdragan@ugal.ro
}

\begin{abstract}
The paper presents the obtained results and the conclusions following the measurements regarding the noise pollution, from the analysed area of Galati. Monitoring has been made for as many factors as possible, possible causes of noise pollution, with the purpose of covering the entire area of development and the activity of oil exploitation. The determinations were made at different time intervals, for several working days, and in the end, they were compared with the regulations required by law regarding the exposure limit value for a normal day of 8 hours. Because the activity of exploration and exploitation of hydrocarbons requires the use of many heavy machinery, which pollute, their noise they can have a significant impact on the environment. For the analysis, several work points were monitored with the purpose of providing an overview, regarding the noise pollution, in the Independence oil exploitation area.
\end{abstract}

KEYWORDS: noise pollution, environment, hydrocarbs exploitation

\section{Introduction}

The analysed area is located on the territory of Galaţi County, about $22 \mathrm{~km}$ away, to the NW, in the vicinity of the localities of Schela and Slobozia Conachi. The acoustic measurements which were made aimed to determine the noise level from the Independența oil area, where a multitude of factors pollute the environment. Noise samples for our analysis were taken from several work points, in order to have a clearer view regarding the noise pollution in the respective area.

The acoustic measurements were made in the Independence oil exploitation area, to determine the noise level in the area. For the analysis, several work points were monitored $[1,3]$.

The sources of noise pollution monitored are:

- probes with repair and intervention activities;

- wells in production activities;

- reservoir parks;

- combustion plants (boilers);

- traffic;

- deposit (treatment area).

The recorded results were obtained, with the multifunctional digital sound measuring instrument, the PCE - 222 Multiparameter (Fig. 1).

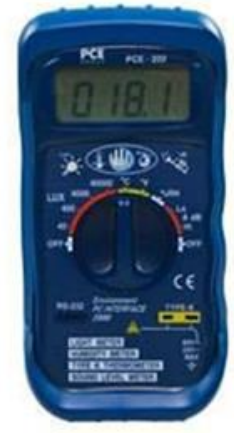

Fig. 1. PCE-222 sound level meter

\section{Experimental research}

\subsection{Noise determinations at wells with repair and intervention activities}

The probes where intervention or repair activities were carried out are noise generators. The tests were conducted over two working days, divided as follows:

- M 1, day 1 - morning, repair probe; in the afternoon, the intervention probe;

- M 2, day 2 - in the morning, the intervention probe; afternoon, repair probe. 
Although the engines of the work facilities are homologated, it was found that, at times, they exceeded the permissible noise level of $87 \mathrm{~dB}$, admitted by the laws in force. The other equipment set at the location did not exceed the noise level, but when their engines were at full speed, they reached the limit of noise pollution [2, 4] provided by law (see Table 1).
The noise level, resulting from the activity of the two probes, in some cases exceed the threshold imposed by law, but considering that the activity is not carried out near the engines of the installations, the workers are not exposed to the risk of noise pollution.

Table 1. Noise determination at repair and intervention probes

\begin{tabular}{|c|c|c|c|}
\hline \multirow{2}{*}{ Probe } & \multirow{2}{*}{$\begin{array}{c}\text { The place where measurements } \\
\text { are made }\end{array}$} & \multicolumn{2}{|c|}{ Noise dB- average value } \\
\hline & & M 1 & M 2 \\
\hline \multirow{5}{*}{ Capital Repair } & The mouth of the probe & $65 / 85$ & $63 / 83$ \\
\hline & Installation AM 12-40 & $70 / 90$ & $69 / 88$ \\
\hline & Motor pump & $63 / 85$ & $61 / 80$ \\
\hline & Drive unit & $62 / 86$ & $60 / 85$ \\
\hline & Outside the square & $55 / 65$ & $55 / 64$ \\
\hline \multirow{4}{*}{ Intervention } & The mouth of the probe & $65 / 85$ & $64 / 83$ \\
\hline & Installation IC 5-T & $70 / 88$ & $70 / 86$ \\
\hline & Drive unit & $63 / 85$ & $63 / 84$ \\
\hline & Outside the square & $56 / 68$ & $55 / 67$ \\
\hline \multicolumn{2}{|c|}{$\begin{array}{l}\text { Exposure limit value (according to GD 493/2006) for a } \\
\text { normal working day of } 8 \text { hours }\end{array}$} & 87 & \\
\hline
\end{tabular}

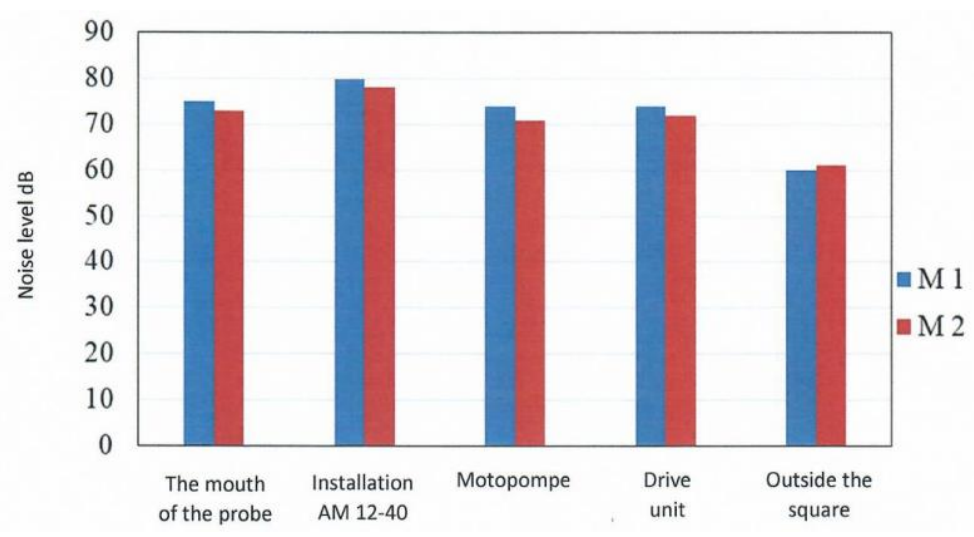

Fig. 2. Average noise level, produced by machine engines - capital repair probe

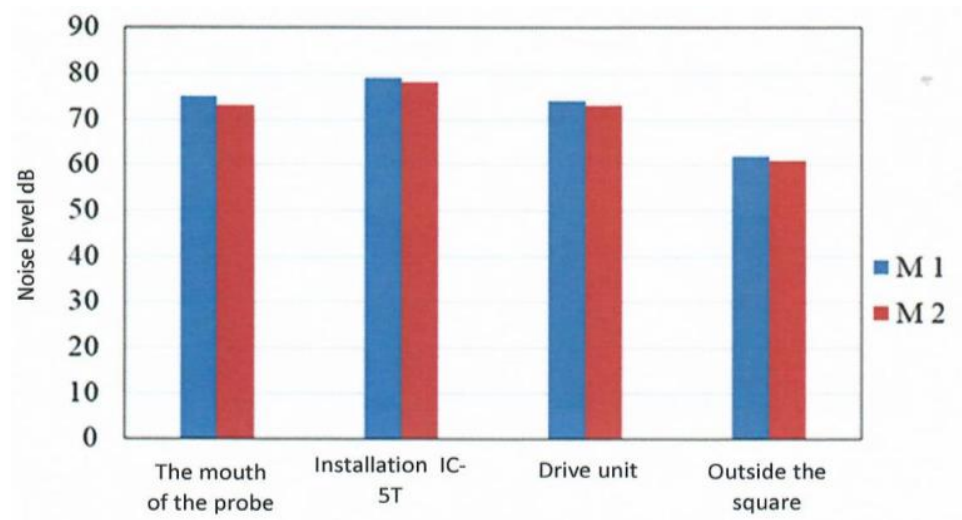

Fig. 3. The average of the noise level produced by the engines of the machines - the intervention probe 
We find that there is no exceedance of the threshold of attention, and therefore, the risk of exposure of workers is not a high one.

\subsection{Noise determination at production wells}

In the exploitation phase of the probes, the potential source of noise is the electric motor. This actuates the rotor, which enters the helical pump, in order to lift the fluids to the surface. Ventilation of the probe (if it contains gases) can be a source of noise. Depending on how they are removed, they can cause noise pollution [5].
The measurements were made near the probe, and on the ring road, near the houses. The monitoring duration was about 30 minutes, for each probe, between 12:00 and 13:00 and the results noted in Table 2 are an average of the noise produced by the drive units at the mouth of the probes.

In order to identify the risk degree of the workers and residents in the vicinity of the monitored objectives, the results were compared with the norms in force regarding the minimum safety and health requirements, regarding the exposure of the workers, the risks generated by the noise, and the permissible limits of noise level, outside the lens and near buildings.

Table 2. Noise determination at production wells

\begin{tabular}{|c|c|c|c|}
\hline \multirow{2}{*}{ Object } & \multicolumn{3}{|c|}{ Noise level - dB } \\
\cline { 2 - 4 } & Near the engine & $\begin{array}{c}\text { At the edge of the } \\
\text { square }\end{array}$ & Near the houses \\
\hline Sample 1 & 85 & 60 & 33 \\
\hline Sample 2 & 80 & 57 & 31 \\
\hline $\begin{array}{l}\text { GD 493/2006, a nominal day } \\
\text { of 8 hours }\end{array}$ & 87 & 65 & $50 / 40$ \\
$\begin{array}{l}\text { Stas 10009-88, outside of the } \\
\text { objective near } \\
\begin{array}{l}\text { Stas 10009 - 88, nuildings (day / night) } \\
\text { build }\end{array}\end{array}$ & & \\
\hline
\end{tabular}

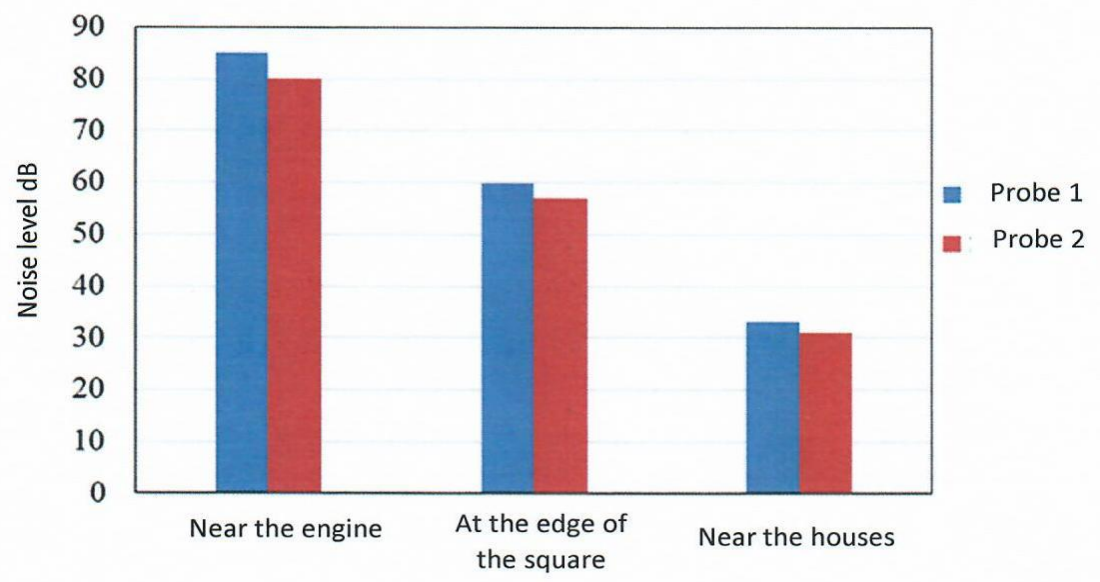

Fig. 4. Average of sound pressure, at the wells in production

Following the measurements made, it was found that the analysed objectives do not exceed, on any of the three points, the noise level required by law. Most of the wells in the vicinity of the dwellings are equipped with sound-absorbing cabins, which have the role of optimizing the noise produced by electric motors. 


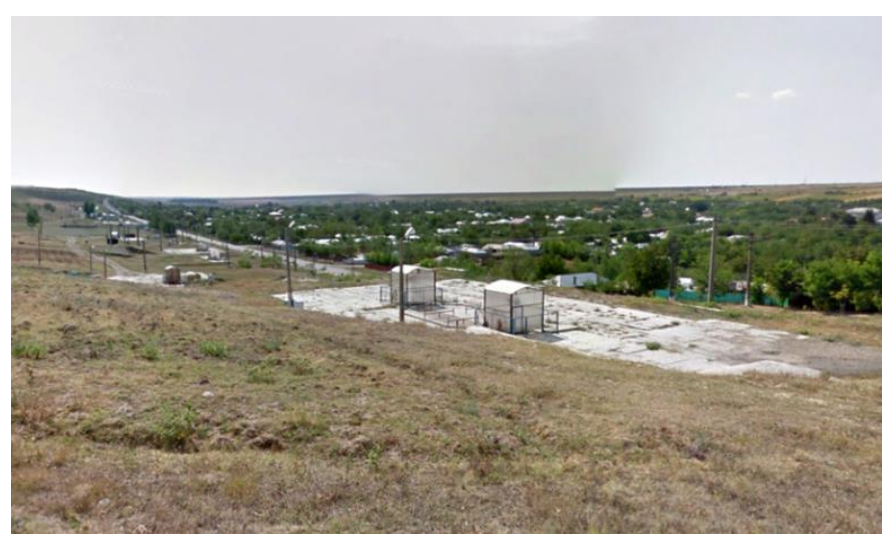

Fig. 5. Illustrative view, at the probes, at the outskirts of the town of Schela, which have soundabsorbing cabs, against the noises

\subsection{Research on noise pollution, in reservoir parks}

Although modernized for their most part, the reservoir parks are still noise generators, through the thermal power plant, the injection pump, the air compressor, the gas manifold, etc.
Two parks, which require personnel, were chosen, in order to track how they were exposed to noise pollution. Some parks are fully automated, and no longer require permanent staff. The operators and maintenance teams go through them periodically, and check the proper functioning of the equipment.

Table 3. Noise level determination, in Park no. 3, Independence

\begin{tabular}{|c|c|c|c|}
\hline \multicolumn{3}{|c|}{ The place where measurements are made } & \multicolumn{2}{|c|}{ Noise - dB } \\
\cline { 2 - 4 } & M 1 & M 2 \\
\hline \multirow{3}{*}{ Park nr. 3 } & The manifold of the gas & 55 & 65 \\
\cline { 2 - 4 } & The boiler & 79 & 80 \\
\cline { 2 - 4 } & Injection pump & 80 & 80 \\
\cline { 2 - 4 } & Air compressor & 84 & 85 \\
\cline { 2 - 4 } & Access alleys & 60 & 62 \\
\hline \multirow{2}{*}{$\begin{array}{l}\text { Exposure limit value (according to GD 493/2006) } \\
\text { for a normal working day of 8 hours }\end{array}$} & & \\
\hline
\end{tabular}

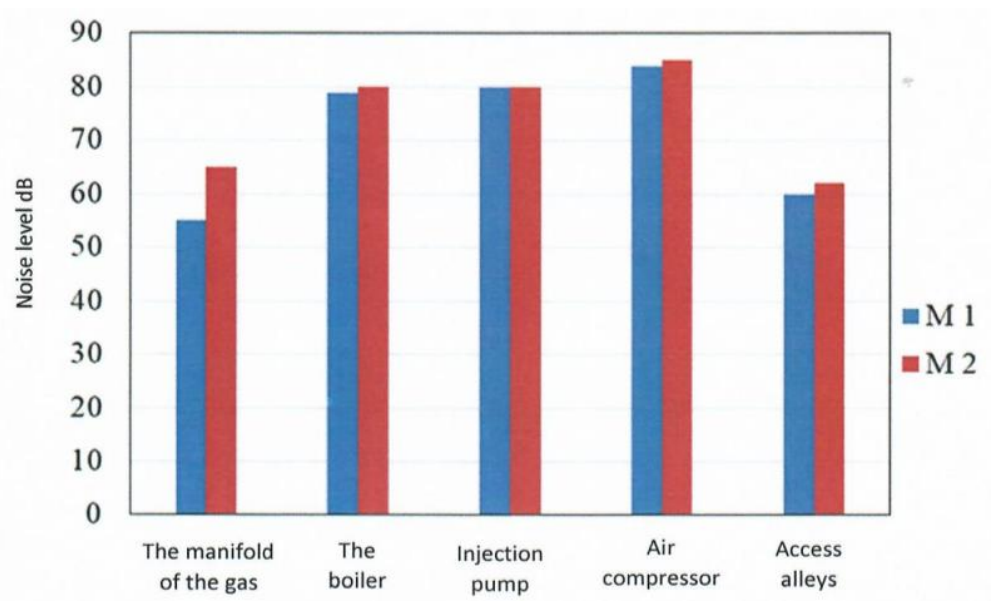

Fig. 6. Results of sound pressure, recorded in Independence Park 3 
The research regarding the noise level in Park No. 3, Independența highlights the fact that although modern, the equipment produces enough noise. The periodic monitoring of the noise pollution is necessary.
The measurements showed that the noise produced by the equipment is generally the same, in both situations; a difference exists only in the case of the gas manifold, which has the role of directing the gases to the waste basket in order to be eliminated.

Table 4. Noise level determination, in Park no. 11, Independența

\begin{tabular}{|c|c|c|c|}
\hline \multirow{2}{*}{ The place where measurements are made } & \multicolumn{2}{|c|}{ Noise - dB } \\
\cline { 2 - 4 } & M 1 & M 2 \\
\hline \multirow{3}{*}{ Park nr.11 } & The boiler & 70 & 58 \\
\cline { 2 - 4 } & Injection pump & 73 & 75 \\
\cline { 2 - 4 } & Air compressor & 84 & 74 \\
\cline { 2 - 4 } & Access alleys & 60 & 54 \\
\cline { 2 - 4 } & $\begin{array}{l}\mid c \\
\text { Exposure limit value (according to GD } \\
\text { 493/2006) for a normal working day of 8 hours }\end{array}$ & \\
\hline
\end{tabular}

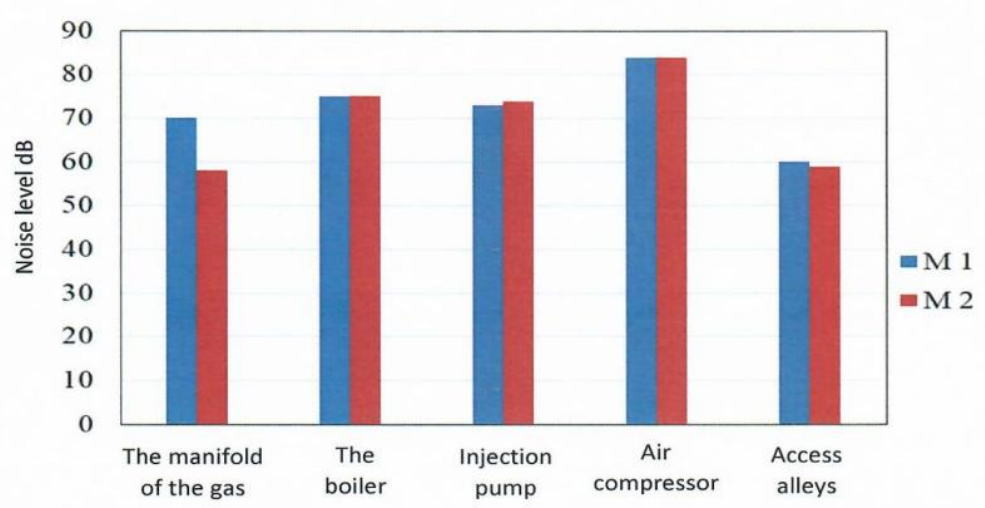

Fig. 7. Noise level determination, in Park no. 11, Independence

\subsection{Noise analysis in the battery with boilers}

The battery with boilers plays an important role in the treatment process, as it provides the hot water necessary for the fluidization of the oil. The two functional boilers produce sufficient noise, which determines a permanent supervision, by the employer, regarding the degree of noise pollution.

The result recorded after the monitoring, showed that the noise level was quite high, sometimes exceeding the alert threshold of $87 \mathrm{~dB}$, provided by the regulations regarding the exposure limit for a nominal day of 8 hours.

Table 5. Noise analysis in the battery with boilers

\begin{tabular}{|c|c|c|}
\hline \multirow{2}{*}{ The place where measurements are made } & M 1 & M 2 \\
\cline { 2 - 3 } & \multicolumn{1}{|c|}{ Noise - dB } \\
\hline \multicolumn{1}{|c|}{ Boiler no. 2 } & 86 & 87 \\
\hline $\begin{array}{l}\text { Exposure limit value (according to GD } \\
\text { 493/2006) for a normal working day of } 8 \\
\text { hours }\end{array}$ & & 84 \\
\hline
\end{tabular}




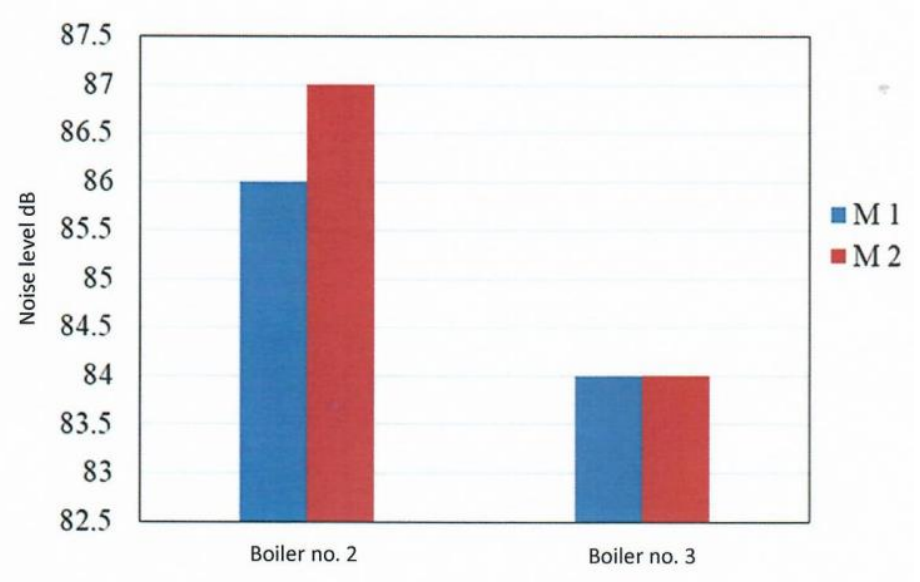

Fig. 8. Noise analysis in the battery with boilers

\subsection{The measurement of noise due to traffic on the area}

The traffic on the ring road was chosen, off the town of Schela was a paved road between two exploitation parks, and a paved road between the wells. The measurements were made over a period of two days, for each day, approximately 30 minutes for each road. During the 30 minutes, as long as the monitoring lasted, an average of the recorded results was made, both during the traffic and in its absence. For comparison, we scored M 1 with the average of the noise level during the traffic and M 2 with the average of its lack.

Table 6. The measurement of noise due to traffic on the area

\begin{tabular}{|c|c|c|}
\hline \multirow{2}{*}{ The place where measurements are made } & \multicolumn{2}{|c|}{ Noise - dB } \\
\cline { 2 - 3 } & M 1 & M 2 \\
\hline The ring road of Schela commune & 72 & 33 \\
\hline Gravel road, between wells & 75 & 36 \\
\hline Paved road between parks & 73 & \multicolumn{2}{|c|}{65} \\
\hline $\begin{array}{l}|c| \\
\text { Stas 10009 - 88, Acoustics in construction; Urban } \\
\text { acoustics - limits allowable at the noise level }\end{array}$ & \multicolumn{2}{|c|}{} \\
\hline
\end{tabular}

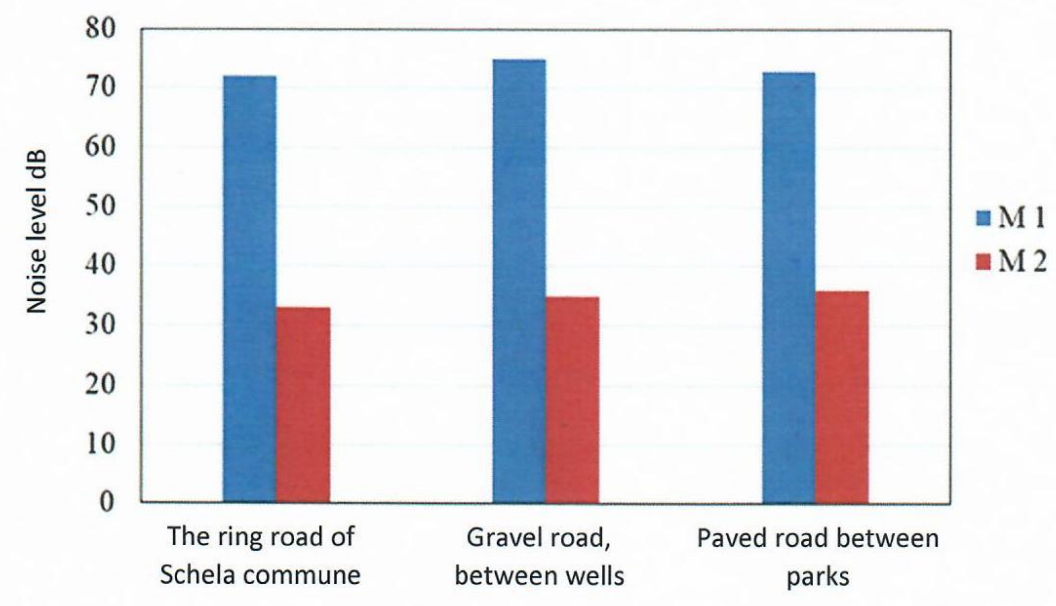

Fig. 9. The measurement of noise due to traffic on the area

As can be seen, the noise level produced by the road traffic exceeds the allowable limit value of 65
$\mathrm{dB}$, outside the objective, provided by the law on construction acoustics and urban acoustics. 


\subsection{Determinations of noise at the central warehouse (treatment area)}

All the fluids extracted from the wells (crude oil and reservoir water) arrive through the parks, which pump the fluids through the pipes in the central warehouse (treatment area). Here, the fluids are first collected in the tanks, where the decanting process takes place, then, after the water has been removed, the remaining oil is subjected to the treatment process. For all these processes (treatment, directing of oil and reservoir water), pumps eliminating the fluids must be used.

Table 7. Determinations of noise at the central warehouse (treatment area)

\begin{tabular}{|c|c|c|c|}
\hline \multirow{2}{*}{\multicolumn{2}{|c|}{ The place where measurements are made }} & \multicolumn{2}{|c|}{ Noise - dB } \\
\hline & & M 1 & M 2 \\
\hline \multirow{5}{*}{ Inside deposit } & Near decanter & 74 & 73 \\
\hline & At the heaters & 73 & 73 \\
\hline & Between tanks & 73 & 73 \\
\hline & At the skid & 74 & 73 \\
\hline & Access alleys & 73 & 72 \\
\hline \multicolumn{2}{|c|}{ Injection pump chamber } & 91 & 90 \\
\hline \multicolumn{2}{|c|}{ Recirculation pump room } & 81 & 81 \\
\hline \multicolumn{2}{|c|}{ Oil pump room } & 83 & 83 \\
\hline \multicolumn{2}{|c|}{$\begin{array}{l}\text { Exposure limit value (according to GD } \\
493 / 2006 \text { ) for a nominal day of } 8 \text { hour }\end{array}$} & \multicolumn{2}{|c|}{87} \\
\hline
\end{tabular}

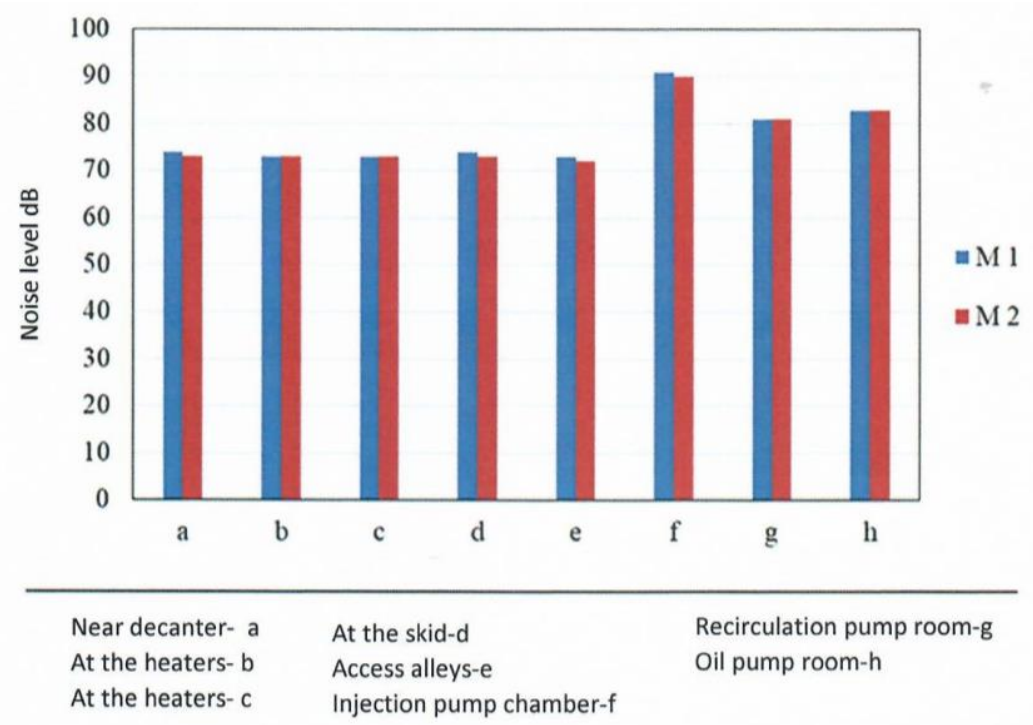

Fig. 10. Determinations of noise at the central warehouse (treatment area)

As a result of the noise monitoring process, the injection pumps, which operated at full capacity were observed to produce a high-level noise of $87 \mathrm{~dB}$, during the 8 working hours, which was above the limit imposed by the regulation. For this reason, the employer provided the workers with noise protection equipment (antiphons).

\section{Conclusions}

The results obtained following the monitoring of the six objectives were compared with the Laws in force regarding the noise pollution: Decision no. 493 of 12.04.2006 [6] and the norms of Standard $10009-$ 88 [7], respectively.

Based on the data regarding the acoustics of the noises, machines and means of transport, under normal operating conditions, the noise level relative to the nearest receiver (human settlements) is below the permissible noise values of $50 \mathrm{~dB}$, according to the regulations in force.

Although there have been exceedances of the noise level in several analysed objectives, the risk of the workers' exposure is not high, because, the 


\section{THE ANNALS OF "DUNAREA DE JOS" UNIVERSITY OF GALATI \\ FASCICLE IX. METALLURGY AND MATERIALS SCIENCE \\ $\mathrm{N}^{\circ} .4$ - 2019, ISSN 2668-4748; e-ISSN 2668-4756 \\ Article DOI: https://doi.org/10.35219/mms.2019.4.05}

activity does not require permanent supervision. Hearing protection is used when necessary.

Under these conditions, a series of measures were taken, to limit to the impact caused by the noise pollution. These will decrease the degree of exposure of the workers. The residents are not exposed, because most of the wells, and absolutely all of the parks are located in the outskirts of the town, and the noises produced do not represent any threat to their health.

The level of exposure at workers is $87 \mathrm{~dB}$ for a period of 8 hours. If the exposure level exceeds the exposure limit value of $87 \mathrm{~dB}$, the employer will have to ensure:

- individual means of hearing protection;

- technical means for noise reduction;

- the organization of the work so as to reduce the noise by limiting the duration and intensity of the exposure and to establish sufficient breaks during the work program.

\section{References}

[1]. Gavrilescu E., Surse de poluare si agenti poluanti ai mediului, Ed. Sitech, ISBN: 978-973-746-462-0, 2007.

[2]. Ioachim G., Popa Gh., Extracția petrolului și gazelor, Editura Tehnică, Bucureşti, 1979.

[3]. Bulău I., Colectarea şi depozitarea ţiţeiului şi gazelor, Institutul de Petrol şi Gaze, Ploieşti, 1978.

[4]. Popa I., Colectarea, tratarea şi transportul petrolului şi produselor petroliere din schelele de producţie, Editura Tehnică şi Pedagogică, Bucureşti, 1985.

[5]. Darabonț Al., Combaterea poluării sonore şi a vibraţiilor, Ed. Tehnică, Bucuresti, 1982.

[6]. ***, Hotărârea nr. 493 din 12.04.2006 privind cerinţele minime de securitate și sănătate referitoare la expunerea lucrătorilor la riscurile generate de zgomot.

[7]. ***, STAS 10009 - 88, Acustica in construcţii; Acustica urbană - limite admisibile ale nivelului de zgomot. 